\title{
KOI HERPES VIRUS: DO ACIPENSERID RESTITUTION PROGRAMS POSE A THREAT TO CARP FARMS IN THE DISEASE-FREE ZONES?
}

\author{
Jolanta KEMPTER ${ }^{1 *}$, Jacek SADOWSKI ${ }^{1}$, Heike SCHÜTZE ${ }^{2}$, Uwe FISCHER ${ }^{2}$, Malte \\ DAUBER $^{2}$, Dieter FICHTNER ${ }^{2}$, Remigiusz PANICZ ${ }^{1}$, and Sven M. BERGMANN ${ }^{2}$ \\ ${ }^{1}$ West Pomeranian University of Technology, Division of Aquaculture, Szczecin, Poland \\ ${ }^{2}$ Friedrich-Loeffler-Institut, Federal Research Institute for Animal Health, Suedufer 10, \\ 17493 Greifswald-Insel Riems, Germany
}

\begin{abstract}
Kempter J., Sadowski J., Schütze H., Fischer U., Dauber M., Fichtner D., Panicz R., Bergmann S.M. 2009. Koi herpes virus: do acipenserid restitution programs pose a threat to carp farms in the disease-free zones? Acta Ichthyol. Piscat. 39 (2): 119-126.
\end{abstract}

Background. Sturgeons have long been extinct in Polish inland waters. A substantial effort has recently been put into their restitution, covering the drainage areas of two major Polish rivers, the Oder and the Vistula. The stocked fishes are clinically healthy, but very little is known about their potential to transmit viral diseases including koi herpes virus (KHV) to healthy fishes of other species, which may pose a threat to the disease-free zones. This study was intended to determine if sturgeons could be asymptomatic carriers of KHV.

Materials and Methods. A total of 29 sturgeons (two species; length 8-37 cm) originating from fish farms in northern Poland with a known KHV history in common carp or koi in the area were examined: 15 Russian sturgeons, Acipenser gueldenstaedtii, with clinical signs of a disease and 14 asymptomatic Atlantic sturgeons, A. oxyrinchus. The former were sent to the laboratory alive while the latter were sent fixed in ethanol. As it is required for detection of a latent KHV infection in acipenserids, two independent procedures were applied. The preliminary results were obtained using PCR. Those findings were subsequently confirmation by nested PCR. The latter procedure consists of sequence analysis of PCR products and direct detection of KHV infected cells in tissue materials by in-situ hybridization on nucleic acid level or indirect immunofluorescence on KHV protein level. Results. KHV genome parts were found in nine Russian sturgeons and four Atlantic sturgeons. Comparison of PCR results obtained from three primer pairs used for KHV diagnostic in sturgeon showed that those designed by Bercovier et al. were most sensitive and robust for this purpose. In order to confirm the presence of viral particles the most useful method was in-situ hybridization (ISH), allowing the detection of KHV in gill samples obtained from live sturgeons.

Conclusion. This preliminary study shows that sturgeons can be carriers of KHV. Therefore a viral diagnostics is highly recommended not only for sturgeons obtained from the environment but also for fertilized eggs, fry, and fish intended for re-stocking measurements of inland waters.

Keywords: Koi herpesvirus, Acipenser gueldenstaedtii, Russian sturgeon, Acipenser oxyrinchus, Atlantic sturgeon, PCR, nested PCR, ISH, iIFA

\section{INTRODUCTION}

In 2003 and subsequent years, a substantial number of Polish fish farms experienced mass mortality of carp (Cyprinus carpio) - their major culture species. Clinical signs have led to the assumption that these heavy losses may have been caused by infection with the koi herpes virus (KHV), which was first isolated and diagnosed in carps from the Rybacka Stacja Doświadczalna (the Fisheries Research Station) of the Agricultural University in Szczecin (Sadowski and Kempter 2004, Bergmann et al. 2006). In the wake of this finding, many research centres in Poland have initiated projects focusing on KHV, in its different aspects, and attempted to develop diagnostic tests for carp cultures (Kempter et al. 2008a). According to the State Veterinary Research Institute in Puławy (Państwowy Instytut Weterynaryjny Państwowy Instytut Badawczy), this problem is not only related to the carp market and the stocking material turnover. The research projects carried out at the Puławy institute focuses mainly on the other species, suspected of being a vector for KHV. This assumption is based on the fact that the clinical signs have hitherto not been observed in any other species except Cyprinus carpio (common carp and koi). Many research facilities, such as the the

\footnotetext{
* Correspondence: Dr Jolanta Kempter, Pracownia Genetyki i Selekcji Ryb, Zakład Akwakultury, Zachodniopomorski Uniwersytet Technologiczny, ul. Kazimierza Królewicza 4, 71-550 Szczecin, Poland, phone: +48914496663, e-mail: jolanta.kempter@zut.edu.pl
} 
University of California Davis, the Central Institute for Animal Disease Control in Lelystad, the Federal Research Institute for Animal Health (Bundesforschungsinstitut für Tiergesundheit) Insel Riems near Greifswald, Germany, and the West Pomeranian University of Technology, Department of Aquaculture, have been trying to compile a list of species which may be asymptomatic vectors of KHV.

Kolman et al. (2005) proposed that KHV-screening should include Acipenseridae, which become increasingly popular not only in private ponds but also in commercial carp farms in Poland. He also emphasized that the fish farmers attempting to reintroduce Atlantic sturgeon into the Vistula and Odra rivers should be informed on the epizootic threat associated with this reintroduction of sturgeons into Polish waters, especially in the areas with carp farms. Inadequate supervision may cause irreversible changes in the wildlife and the aquaculture as a result of the newly introduced viruses, threatening not only carp but also the sturgeon itself. Preliminary detection attempts in sturgeons yielded not only KHV but also white sturgeon-like iridovirus (WSIV) and a sturgeon herpesvirus. This finding constitutes a great hazard because of joint occurrence of three viral disease agents (Sven M. Bergmann, personal communication).

Sturgeons imported from Canada are exempted from any virological diagnostics because of the lack of relevant legislation. Consequently, asymptomatic carriers of KHV, may spread this disease agent to carp farms. Taking into account the intensive sturgeon culture and the extensive common carp farming (Kolman et al. 2005), it is necessary to conduct research on possible KHV carriers in a controlled environment but also on the health of the introduced sturgeons themselves.

\section{MATERIALS AND METHODS}

Russian sturgeon (Acipenser gueldenstaedtii, $n=15$ ) and Atlantic sturgeons (A. oxyrinchus, $n=14)$ collected from two polyculture farms located in the northern part of Poland. The Russian sturgeons came from cages (Rybacka Stacja Doświadczalna - the Fisheries Research Station) kept in the cooling water of the Dolna Odra power plant at Nowe Czarnowo. The total length (TL) of the Russian sturgeons ranged from 25 to $37 \mathrm{~cm}$. External examination included the fin bases, where haemorrhages were observed. Postmortem examination of the internal organs showed partial lysis of the spleen and liver, ascites and swollen intestines. Moreover, the gills were pale to grey and were covered with a grainy deposit. The sturgeons were weak and died at the rate of 2 to over a dozen per cage. The highest mortalities coincided with the water temperatures ranging from 25 to $32^{\circ} \mathrm{C}$.

The Atlantic sturgeons originated from the Saint John River, New Brunswick, Canada and were imported to Poland as fry. Their total length ranged from 8 to $12 \mathrm{~cm}$ and they were fixed with $96 \%$ ethanol for transportation to the laboratory. None of them showed any pathological signs on the gills or skin before fixation, nevertheless single dead fish were also observed (Rzemieniecki, personal communication).
Gill swabs Russian sturgeon. The sturgeons were removed from the water and the gills were swabbed with autoclaved ear sticks. Two ear sticks (containing some blood) were collected from each fish, were stored in

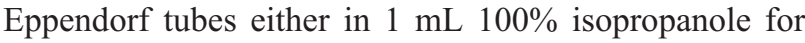
fluid DNA extraction by DNAzol® genomic DNA isolation reagent (Invitrogen) or $0.5 \mathrm{~mL}$ lysis buffer with proteinase $\mathrm{K}$ for extraction by DNeasy Blood and Tissue kit or QIAamp DNA mini kit (Qiagen) at room temperature. For fluid extraction, tubes were vigorously shaken for 10 min and centrifuged at $5000 \mathrm{rpm}, 4^{\circ} \mathrm{C}$ for $20 \mathrm{~min}$ (Hettich centrifuge). After removing the alcohol, the remaining pellet was allowed to dry at room temperature for 10 to 15 min, then $1 \mathrm{~mL}$ DNAzol was added and vigorously shaken for at least $1 \mathrm{~h}$. Afterwards, DNA extraction was performed according to the manufacturer's instructions with some minor modifications. DNA was precipitated with ice-cold $100 \%$ ethanol $(0.5 \mathrm{~mL})$ through centrifuging at $1000 \times \mathrm{G}$, for $10 \mathrm{~min}$ at $4^{\circ} \mathrm{C}$, washed twice with ice-cold ethanol $75 \%(1 \mathrm{~mL})$ by centrifugation at $800 \times \mathrm{G}$, for 10 $\min$ at $4{ }^{\circ} \mathrm{C}$, then alcohol was removed, the pellet allowed to dry for 10-15 min at room temperature and finally solubilized in $50 \mu \mathrm{L}$ water (DNase and RNase free). Extractions on silicate columns were exactly done according to the manufacturer's instructions.

DNA extraction from tissue material. Organ tissues (25-50 mg) were ground using a hand mixer (Roth), subsequently DNA was extracted from liver, kidney, heart, and gut according to the DNAzol method as described above and without previous grinding from lysed leucocytes adjusted to $1 \times 10^{7}$ leukocytes $\cdot \mathrm{mL}^{-1}$.

KHV detection by PCR. PCRs for detection of KHV fragments were done according to assays published by Gilad et al. (2002), Bergmann et al. (2006), and Bercovier et al. (2005) (Table 1). All samples investigated according to the method of Gilad et al. (2002) were confirmed under the same conditions by nested PCR using $2 \mu \mathrm{L}$ of Gilad's PCR product and the primer pair KHV 1Fn-1Rn (Bergmann et al. 2006). As positive control DNA obtained from CCB cells replicated KHV-I (Gilad et al. 2002) was used. Channel catfish herpesvirus (CCV), carp pox virus (CyHV-1), goldfish haematopoietic necrosis herpesvirus (CyHV-2), and herpesvirus anguillae (HVA) were used as heterologous virus controls (negative controls). Organ samples from carp without KHV history (specific pathogen free, University of Wageningen, the Netherlands) were used as negative preparation controls. For each test from preparation to nested PCR, water controls were included. PCR products were visualized in $1.5 \%$ agarose gel containing ethidium bromide. Each PCR and nested PCR was repeated at least twice.

Leukocyte separation. Fish were anesthetized and blood was collected by puncture of the caudal vein into a syringe previously rinsed with heparin (Sigma) at $1000 \mathrm{U} \cdot \mathrm{mL}^{-1}$. Blood was immediately diluted into a five-fold volume of cold CCB cells culture medium containing 10\% fetal calf serum. Prediluted blood was layered onto Ficoll 1077 (Biochrom) or Percoll 1075 (Amersham Bioscience). 
After centrifugation at $650 \times \mathrm{G}$ at $4^{\circ} \mathrm{C}$ for $40 \mathrm{~min}$, white cells at the interphase were collected and washed twice with sterile $\mathrm{PBS}^{-}\left(200 \times \mathrm{G}, 4^{\circ} \mathrm{C}, 10 \mathrm{~min}\right)$ to remove the density gradient. Then leucocytes were adjusted to highest $10^{7}$ cells $\cdot \mathrm{mL}^{-1}$ in $\mathrm{PBS}^{-}$and used for further testing.

Indirect immunofluorescence assay (iIFA) using separated leucocytes. Two drops $(25 \mu \mathrm{L}$ each $)$ of separated and adjusted leukocytes in bovine serum were placed on poly-L lysine covered slides and allowed to dry on air. After framing with a Pap pen (Kisker Biotech), cells were fixed with a mixture of methanol and acetone $(20: 80 \mathrm{v} / \mathrm{v}$ ) for $10 \mathrm{~min}$ at room temperature. The dried drops were washed twice with $\operatorname{PBS}^{(-)}$. Afterwards rabbit KHV-antiserum T 36 (dilution $1: 10$ 000) and anti-KHV monoclonal antibody 10A9 were incubated on the drops for $1 \mathrm{~h}$ at ambient temperature, respectively. After washing again, slides were incubated with FITC-labelled conjugate (Dako) for $1 \mathrm{~h}$ at ambient temperature for detection of mouse and rabbit immunoglobulin, respectively, covered by fluorescence mounting medium containing 1.4-Diazabicyclo[2.2.2] octan, glycerol in $\mathrm{PBS}^{(-)}$at $\mathrm{pH} 8.6$ and propidium iodide in dilution $1: 1000$. Positive signals were observed as greenish-yellow spots connected to the cytoplasm of the obviously infected cells. Propidium iodide counterstaining coloured the cell nuclei red.

Sequence analysis of PCR products. PCR and nested PCR products were eluted from agarose gels and purified with the QIAquick Gel Extraction Kit (Qiagen). DNA was sequenced using the Prism BigDye Terminator v1.1 Cycle Sequencing Kit on the DNA sequencer "3130 Genetic Analyzer" (both Applied Biosystems). Sequencing reactions were performed using the primers pairs according to Gilad et al (2002) and KHV-1Fn and 1 Rn (Bergmann et al. 2006). Sequence data were assembled and edited with GCG, Version 11.1 (Accelrys Inc.).

In-situ hybridization (ISH). Probes were produced by PCR (Eppendorf Mastercycler) using the DIG-Labelling kit according to the manufacturer's instructions (Roche). Organ specimens were formalin-fixed and paraffin-embedded according to standard protocols. Sections of 5-7 $\mu \mathrm{m}$ were placed on Superfrost ${ }^{\circledR}$ microscope slides (Microm International) for $18 \mathrm{~h}$ at $62^{\circ} \mathrm{C}$, dewaxed by $2 \times$ Rotihistol (Roth) for $10 \mathrm{~min}$, followed by $2 \times 100 \%$ ethanol for $10 \mathrm{~min}$, and air dried. Sections were framed by PapPen (Merck), treated with proteinase K (100 $\mu \mathrm{g}$ proteinase $\left.\mathrm{K} \cdot \mathrm{mL}^{-1}\right)$ in TE buffer $(50 \mathrm{mM}$ Tris, $10 \mathrm{mM}$ EDTA) for $20 \mathrm{~min}$ at $37^{\circ} \mathrm{C}$ and fixed again by $95 \%$ ethanol followed by $100 \%$ ethanol for $1 \mathrm{~min}$, respectively. After air drying sections were framed by Pap Pen again and, for equilibration, covered by hybridization mixture (ISH-M) containing $4 \times$ standard saline citrate (SSC), $50 \%$ formamide, $1 \times$ Denhardt's reagent, $250 \mu \mathrm{g}$ yeast tRNA $\cdot \mathrm{mL}^{-1}$ and $10 \%$ dextran sulphate and incubated for one hour at $42^{\circ} \mathrm{C}$ in a humid chamber. DIG-labelled probes prepared with the primer pair $(5 \mu \mathrm{L}$ in $200 \mu \mathrm{L}$ ISH-M) were added to the sections and covered by an ordinary cover slip, placed on the in-situ plate of a thermal cycler (Eppendorf Master Gradient) and heated to $95^{\circ} \mathrm{C}$ for $5 \mathrm{~min}$ for denaturation of DNAs. Then slides were cooled on ice for $2 \mathrm{~min}$ and incubated overnight at $42^{\circ} \mathrm{C}$ in a humid chamber for hybridization. The next day, cover clips were removed by washing in $2 \times \mathrm{SSC}$ twice for $10 \mathrm{~min}$. For removal of unspecific bound probes, slides were incubated in $0.4 \times \mathrm{SSC}$ at $42^{\circ} \mathrm{C}$ for $10 \mathrm{~min}$. Sections were counterstained with Bismarck-Brown Yellow (BBY) for sharpening and contrasting a possible positive signal which becomes visible as violet-black foci in infected cells.

Species differentiation. Sturgeon species were identified using PCR method that had been applied to the amplification of a nucleotide sequence of the mitochondrial genome (cytochrome b) of both species. Amplification of DNA was carried out in a total volume of $25 \mu \mathrm{L}$ in $0.2 \mathrm{~mL}$ tubes containing PCR buffer $[20 \mathrm{mM}$ Tris $\pm \mathrm{HCl}$ ( $\mathrm{pH} 8.4$ ), $50 \mathrm{mM} \mathrm{KCl}], 2.5 \mu \mathrm{L} \mathrm{MgCl}_{2}, 0.5 \mu \mathrm{L}$ of each dNTP, $0.5 \mu \mathrm{L}$ of each primer [L14735 (Burgener and Hübner 1998): 5' aaa aac cac cgt tgt tat tca act a 3'; H15149 (Kocher et al. 1989): 5' gec cct cag aat gat att tgt cct ca 3'], 1 unit of Taq DNA polymerase (Promega Gold Taq Flexi) and 25 ng DNA-template.

The cycling conditions on an Eppendorf thermal cycler (Mastercycler Gradient) were as follows: $3 \mathrm{~min}$ at $94^{\circ} \mathrm{C}$ for initial denaturation, 30 cycles of amplification $\left(15 \mathrm{~s}\right.$ at $94^{\circ} \mathrm{C}, 60 \mathrm{~s}$ at $66^{\circ} \mathrm{C}, 30 \mathrm{~s}$ at $\left.72^{\circ} \mathrm{C}\right)$ and final extension for $7 \mathrm{~min}$ at $72^{\circ} \mathrm{C}$. PCR products were analyzed by gel electrophoresis through a $1.5 \%$ agarose gel in $1 \% \mathrm{TBE}$

Table 1

Primer pairs used in this study

\begin{tabular}{lcccc}
\hline Primer pair & Sequence (5'-3') & $\begin{array}{c}\text { KHV-I (DQ177346) nt } \\
\text { position }\end{array}$ & $\begin{array}{c}\text { Product } \\
\text { size }\end{array}$ & Reference \\
\hline KHV-F (KHV9/5F) & GACGACGCCGGAGACCTTGTG & $165.435-165.455$ & \multirow{2}{*}{ 484 bp } & Gilad et al. (2002) \\
KHV-R (KHV9/5R) & CACAAGTTCAGTCTGTTCCTCAAC & $165.918-165.985$ & & \\
KHV-1Fn & CTCGCCGAGCAGAGGAAGCGC & $165.465-165.485$ & \multirow{4}{*}{ (14 bp } & Bergmann et al. (2006) \\
KHV-1Rn & TCATGCTCTCCGAGGCCAGCGG & $165.878-165.857$ & & \\
KHV-Tkf & GGGTTACCTGTACGAG & $96.087-96.102$ & \multirow{2}{*}{409 bp } & Bercovier et al. (2005) \\
KHV-Tkr & CACCCAGTAGATTATGC & $96.496-96.480$ & & \\
\hline
\end{tabular}


buffer ( $89 \mathrm{mM}$ Tris, $89 \mathrm{mM}$ boric acid, 2mM EDTA) and stained by ethidium bromide. As size reference a $100 \mathrm{bp}$ ladder (PeqLab) was used.

To distinguish the Siberian sturgeon $(A$. baerii) and the Russian Sturgeon (A. gueldenstaedtii) the obtained PCR products were cut with RsaI restriction endonuclease (RE) resulting in species-specific restriction fragment length polymorphisms (RFLP). $10 \mu \mathrm{L}$ of PCR mixture were digested using two units of restriction enzyme (RE) at the recommended temperature for $3 \mathrm{~h}$. Restriction fragments were separated on a $1.5 \%$ agarose gel and the size of DNA fragments was determined in comparison with a 100 bp ladder (PeqLab).

\section{RESULTS}

PCR. After DNA extraction, all samples were used in different PCR assays. In case of the standard PCR according to Gilad et al. (2002) followed by nested PCR (Bergmann et al. 2006) positive results were obtained for A. gueldenstaedtii and A. oxyrinchus. Each PCR and nested PCR was repeated at least twice.

Positive results were marked by a $414 \mathrm{bp}$ band in gels obtained from samples of both, A. gueldenstaedtii and A. oxyrinchus (Table 2). Examination of gill swabs revealed a strong band especially by nested PCR using primer pair KHV 1Fn-1Rn according to Bergmann et al. (2006) (Fig. 1). Two out of 10 samples were positively marked on the gels. Using

PCR results with different pair of primers

\begin{tabular}{|c|c|c|c|}
\hline Species & $\begin{array}{c}\text { PCR } \\
(\text { Gliad et al. 2002) }\end{array}$ & $\begin{array}{c}\text { Nested PCR } \\
\text { (Bergmann 2006) }\end{array}$ & $\begin{array}{c}\text { PCR } \\
\text { (Bercovier 2005) }\end{array}$ \\
\hline A. gueldenstaedtii & - & - & + \\
\hline A. gueldenstaedtii & - & - & + \\
\hline A. gueldenstaedtii & - & - & + \\
\hline A. gueldenstaedtii & - & - & + \\
\hline A. gueldenstaedtii & - & - & + \\
\hline A. gueldenstaedtii & - & - & + \\
\hline A. gueldenstaedtii & - & - & - \\
\hline A. gueldenstaedtii & - & - & + \\
\hline A. gueldenstaedtii & - & - & + \\
\hline A. gueldenstaedtii & - & - & + \\
\hline A. gueldenstaedtii & - & - & + \\
\hline A. gueldenstaedtii & - & - & + \\
\hline A. gueldenstaedtii & - & - & + \\
\hline A. gueldenstaedtii & - & - & + \\
\hline A. gueldenstaedtii & - & - & + \\
\hline A. oxyrinchus & - & - & - \\
\hline A. oxyrinchus & - & - & + \\
\hline A. oxyrinchus & + & + & + \\
\hline A. oxyrinchus & - & + & + \\
\hline A. oxyrinchus & - & - & - \\
\hline A. oxyrinchus & - & - & + \\
\hline A. oxyrinchus & - & - & - \\
\hline A. oxyrinchus & - & - & - \\
\hline A. oxyrinchus & - & - & - \\
\hline A. oxyrinchus & - & - & - \\
\hline A. oxyrinchus & - & - & - \\
\hline A. oxyrinchus & - & - & - \\
\hline A. oxyrinchus & - & + & - \\
\hline A. oxyrinchus & - & - & - \\
\hline
\end{tabular}

a PCR procedure (Gilad et al. 2002), only one tissue sample (single pool of gill, gut, kidney, heart, and spleen tissue) from $A$. oxyrinchus was considered to be positive for KHV DNA. With all other samples used with PCR (Gilad et al. 2002), no bands were observed in the gels. Only the nested PCR protocol according to Bergmann et al. (2006) displayed positive signals (414 bp) from seven Russian sturgeon and two Atlantic sturgeon samples (Fig. 2).

Sequence analyses. PCR products were sequenced directly. Independently nested PCRs obtained from 3 different sturgeon PCRs were analysed. The nucleotide sequences analysed here cover nt 165465-165878 of the published KHV-I sequence (DQ 177346; Aoki et al. 2007). All products were composed of the same sequence and were $100 \%$ identical to the respective region of the published KHV-I and KHV-U (Aoki et al. 2007) sequence.

iIFA. Separated leucocytes from sturgeons were investigated by iIFAT using a polyclonal rabbit anti-KHV antiserum (T 36, dilution 1: 10000 in $\operatorname{PBS}^{(-)}$and a mab named 10A9 (dilution $1: 5$ in PBS). While after counterstaining KHV negative rabbit serum and an irrelevant mab displayed only the red coloured DNA containing cell nuclei (Figs. 3-5), T 36 and mab 10A9 labelled KHV proteins in polymorphic granulocytes mainly (Figs. 4, 6). The iIFA with the polyclonal antiserum T 36 displayed also a weak dark green background reaction in the cytoplasm of all leucocytes, visible in Fig. 3, which was also found when a negative rabbit serum used as negative control. No background was found in reactions with the mabs.

ISH. Formalin-fixed and paraffin-embedded tissue from sturgeon was used for ISH to recognize viral DNA in different organs. After Bismarck-Brown-Yellow (BBY) counterstaining KHV bearing cells were found in gill and kidney tissue. Only in one part of one sample of the gills a massive concentration of infected cells was discovered (Figs. 7-10). In most cases two to five infected cells were observed in gill and kidney tissues (Figs. 7-10). No matches considered to be positive for KHV DNA were found in brain, gut or heart samples (Figs. 11-13).

Species differentiation in sturgeon samples. After digestion of 462 bp long PCR products with RsaI restriction endonuclease (RE) a specific RFLP pattern was seen. Digestion of this amplified fragment resulted in four fragments, one obtained from $A$. baeri and three from A. gueldenstaedtii. Using these RFLP patterns all sturgeons were identified as $A$. gueldenstaedtii, except samples from $A$. oxyrinchus.

\section{DISCUSSION}

According to FAO (Anonymous 2008) data, $300 \mathrm{t}$ of sturgeons are cultivated in Polish fish farms every year. This number includes all species, although Russian sturgeon which accounts for a high percentage of the whole production. At the conference held in Przesiek (Poland) in 2008 focussing on problems of the stocking and the active protection of natural sturgeon populations, Kolman (2008) presented a preliminary procedure for reintroduc- 
tion of Atlantic sturgeon (A. oxyrinchus) into Polish waters. According to the above-mentioned author, the master plan consisted of two stages. The first step was to rear sturgeons, imported from Canada, under aquaculture conditions. The second step consisted of introducing these fish into the natural environment.

The application of health control procedures prior to the first contact with the new habitat is crucial. In addition to many other pathogens (bacteria, fungi, or parasites) there is a serious danger of spreading viruses indigenous to Polish waters and of viruses introduced from the place of origin of the fish. Irido- and herpesvirus were detected

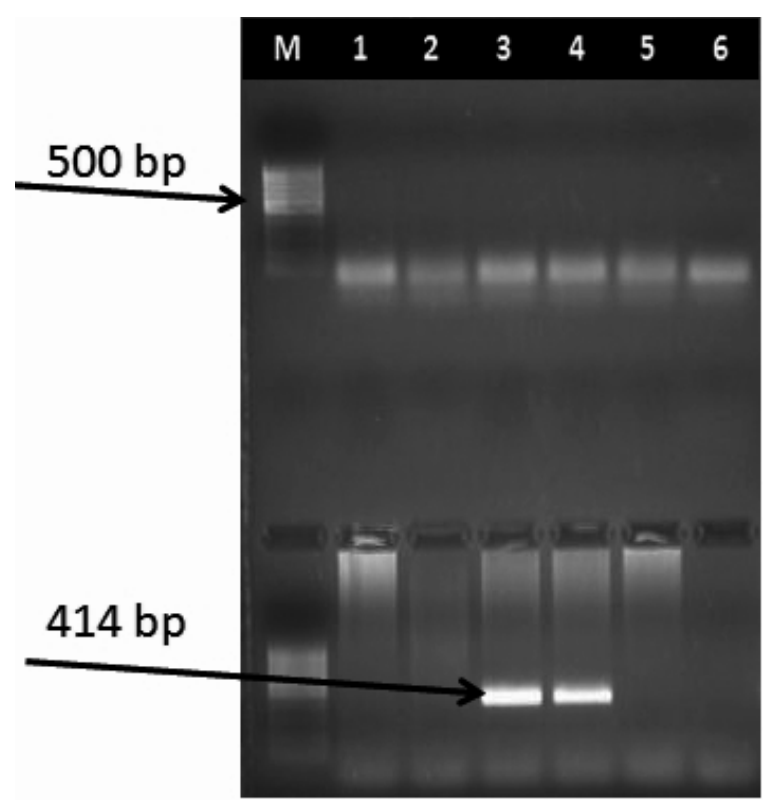

Fig. 1*. Fig. 1. Detection of KHV in gill swabs obtained from Russian sturgeon (A. gueldenstaedtii) by: PCR (methodology of Gilad et al. 2002-upper lines PCR) and nested PCR (methodology of Bergmann et al. 2006-lower lanes) lane 1 sturgeon 6 , lane 2 sturgeon 7 , lane 3 sturgeon 8 , lane 4 sturgeon 9, lane 5 sturgeon 10, lane 6 negative preparation control

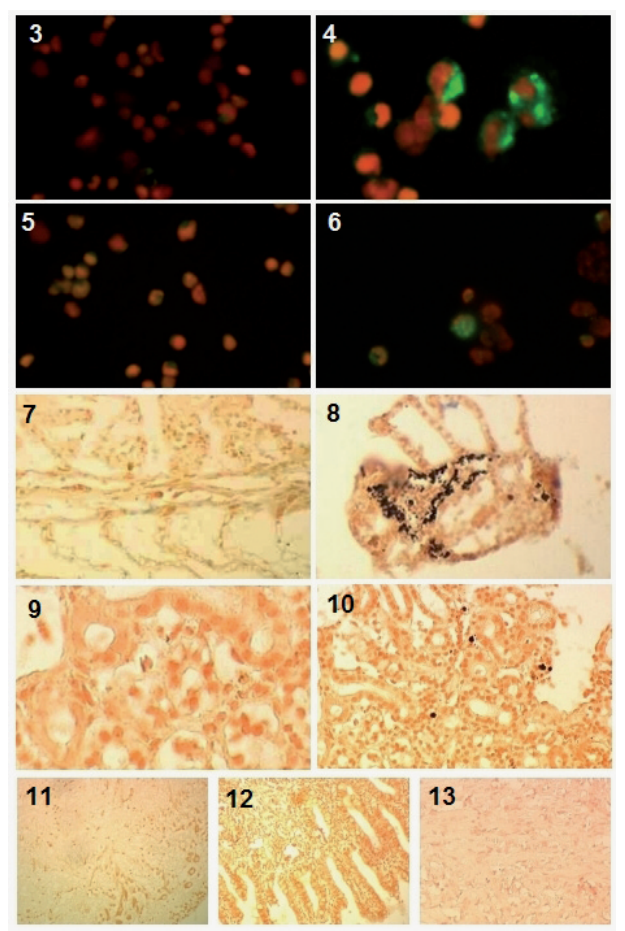

Fig. 3-13*. Detection of KHV in sturgeons; microscopic images; Figs. 3-6. KHV in separated sturgeon leukocytes by iIFAT using a polyclonal antiserum from rabbit and mab 10A9 against KHV; Fig. 3. Negative control rabbit serum; Fig. 4. Detection of $\mathrm{KHV}$ in polymorphic granulocytes with rabbit antiKHV serum T 36 (dilution 1 : 10 000); Fig. 5. Negative control with an irregular mab; Fig. 6. $\mathrm{KHV}$ in polymorphic granulocytes with anti-KHV mab 10A9 (dilution 1 : 5); Figs. 7-10. In-situ hybridization from sturgeon tissues with probe NH1-NH2 (methodology of Hutoran et al. 2005) and BBY counterstaining; Fig. 7. KHV-negative gill fragment; Fig. 8. KHV-positive gill fragment; Fig. 9. KHV-negative kidney fragment; Fig. 10. KHV-positive kidney fragment; Figs. 11-13. ISH of sturgeon organs (probe NH1-NH2) BBY counterstaining; Fig. 11. Brain; Fig. 12. Gut; Fig. 13. Heart

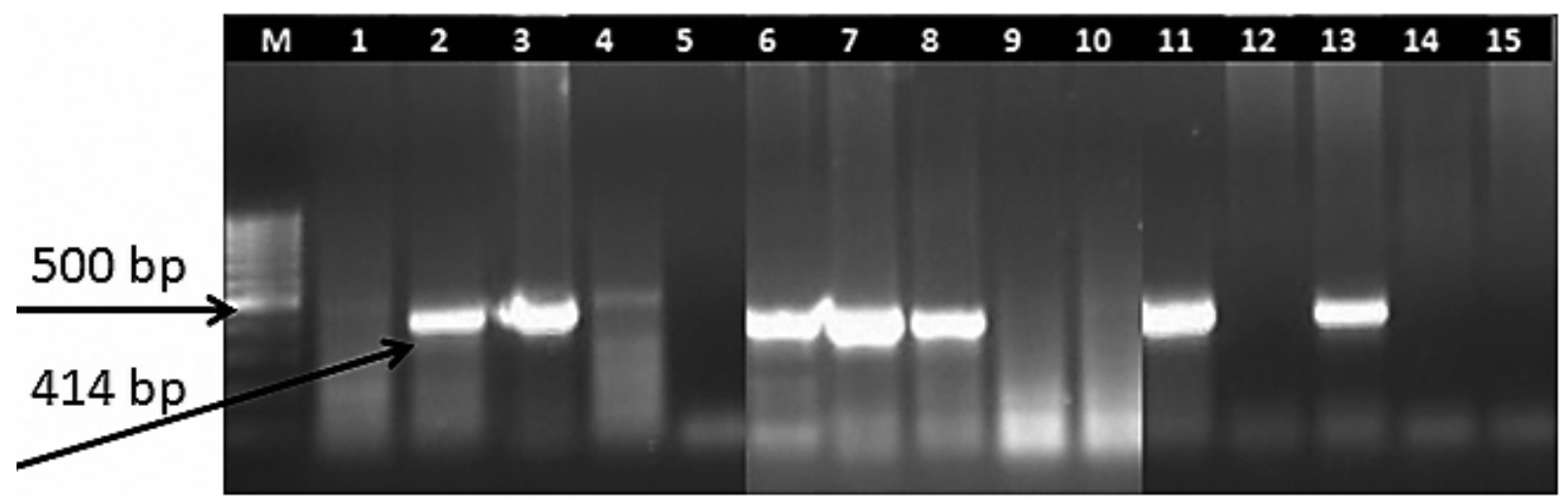

Fig. 2*. KHV detection from tissue samples of different sturgeon by nested PCR (methodology of Bergmann et al. 2006) using $1 \mu \mathrm{l}$ of the first round of PCR product as template; M: 100 bp marker (peqlab); lanes 1-4 A. gueldenstaedtii; lane 5 negative preparation control; lanes 6-10 A. gueldenstaedtii; lanes 11-14 A. oxyrinchus; lane 15 negative control carp kidney

*The authors assume sole responsibility for the quality of photographs 


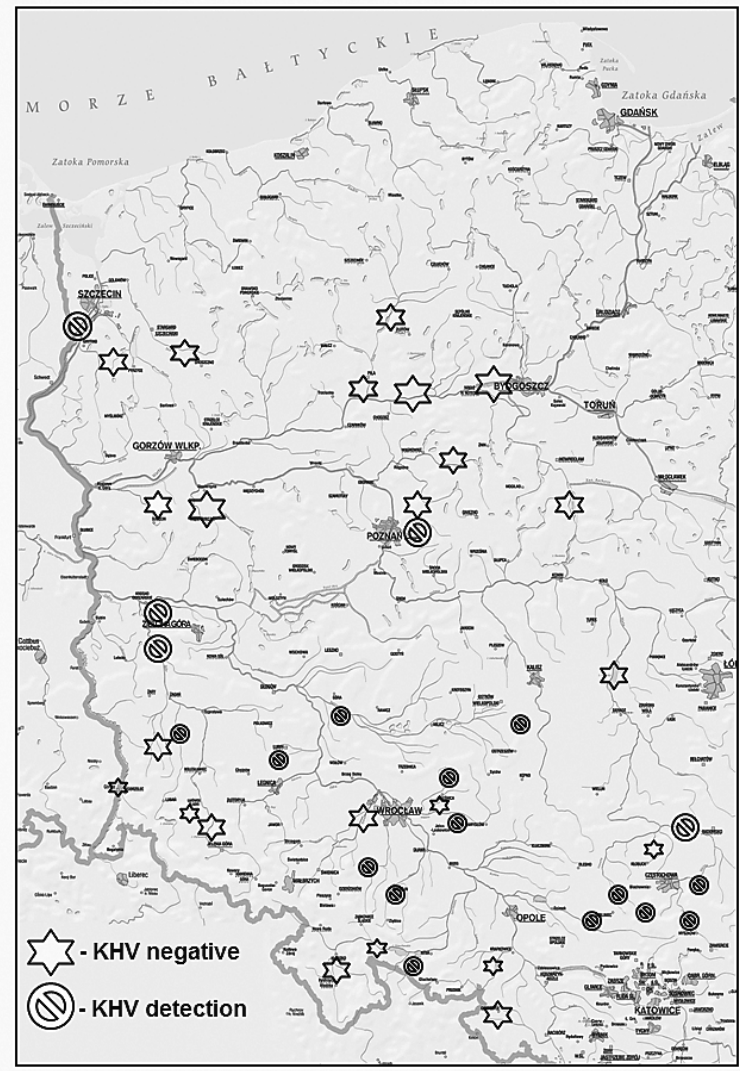

Fig. 14. Investigated river system in western Poland

by PCR in Russian and Atlantic sturgeons reared in Polish carp culture centres (e.g., WSIV or its European or Asian relatives) which also poses a great threat to fish itself and the environment. Based on the fact that in the presently reported study KHV was detected in the specimens collected from Russian and Atlantic sturgeon it seems that restocking should be accompanied by a control management, focusing especially on viruses. This is crucial, as by use of diagnostic methods, such as nested PCR or realtime PCR, even $10 \mathrm{fg}$ of viral DNA, corresponding to 5-10 KHV genomic equivalents measured by realtime PCR (Gilad et al. 2004), can be detected. The use of molecular tools for KHV detection can provide an efficient control of invasive species introduced into local waters. Moreover, both sturgeon species should be closely monitored for KHV infection, especially during the first part of the project. There has been no information available on possible records of the virus in sturgeons. We also know nothing about the potential of those fish to transfer the infection (if confirmed) to carp. Polish fish farms often practice polyculture, which also includes sturgeon (Sadowski, personal observation). It means that Atlantic sturgeon imported from Canada will be kept together with other species, e.g., carp, in the same fish farm, often in the same ponds or at least in the same water. Therefore fish farmers must be instructed that sturgeon and carp should not be kept together in the same water, filter systems, or ponds. The lack of systematic virus control for $A$. oxyrinchus may cause a virus spread also into entire river systems. Consequently carp farms located in the these river systems, selected for sturgeon restocking, may become infected with (e.g., a study on the presence of KHV in the drainage of the Odra River has been conducted under the patronage of the state-financed project SPO RYBY and shown that KHV is present in Polish waters (Kempter et al. 2008).

The rivers regarded KHV-free because of negative virus detection are shown on the map (Fig. 14) (Kempter et al. 2008 a). Introduction of sturgeons (1500 individuals) into the Drwęca River in 2006 and into the Drawa River (150 individuals) in 2007 without verification of their virological status may easily change the KHV-free status of those bodies of water (Fig. 15). Kolman et al. (2007) described the fact that fish introduced into natural waters tend to move downstream because many of them were found in the Notec and Warta rivers.

We believe that any future projects aimed at stocking sturgeons into Polish rivers (and other European rivers as well) should include strict virus detection- and certifications procedures. (Haenen and Engelsma 2004, Haenen and Hedrick 2006, Kempter et al. 2007). Many fish reared in polycultures are potentially dangerous in terms of $\mathrm{KHV}$ epidemiology as they increase the number of pathways of virus spreading. We have also compiled a list of farmedand wild fish species where the presence of KHV DNA was confirmed by PCR or nested PCR. These fish species were either artificially or naturally KHV infected: goldfish (Carassius auratus auratus), crucian carp (C. carassius), grass carp (Ctenopharyngodon idella), bighead carp (Aristichthys nobilis), silver carp (Hypophthalmichthys molitrix), tench (Tinca tinca), wels catfish (Silurus glanis), vimba (Vimba vimba), and Prussian carp (C. carassius gibelio).

Finally, we demonstrated that KHV can be present in sturgeon tissues, perhaps latently or persistently, which was proved on the genomic level by PCR, sequence analysis of PCR products and ISH, but also on the protein level by iIFAT. With regards to the detection of viral proteins in polymorphic granulocytes which normally have $T_{1 / 2}$ period of between 10 and 30 days in fish, it is unknown if the virus is dispatched from the cell under its normal function or if it infects this cell population per se as viral targets. If so, the virus has to be replicated continuously in small amounts to survive (Miyazaki, personal communication). This study raised a number of questions but also produced new findings. In our opinion, KHV detection in different fish should be supported by different PCR procedures and/or confirmed by other tests like ilFAT or ISH. The transmission pathways of KHV from sturgeon to carp should also be investigated to clarify the vector status of these fish. At present, the origin of the KHV infecting sturgeons is unknown, but it is evident that asymptomatic acipenserid carriers of the virus may have a negative effect on carp aquaculture. Implementation of suitable fish-health procedures, involving reliable virus detection methods, for fish used for restocking of natural bodies of water seems to be urgently necessary. 


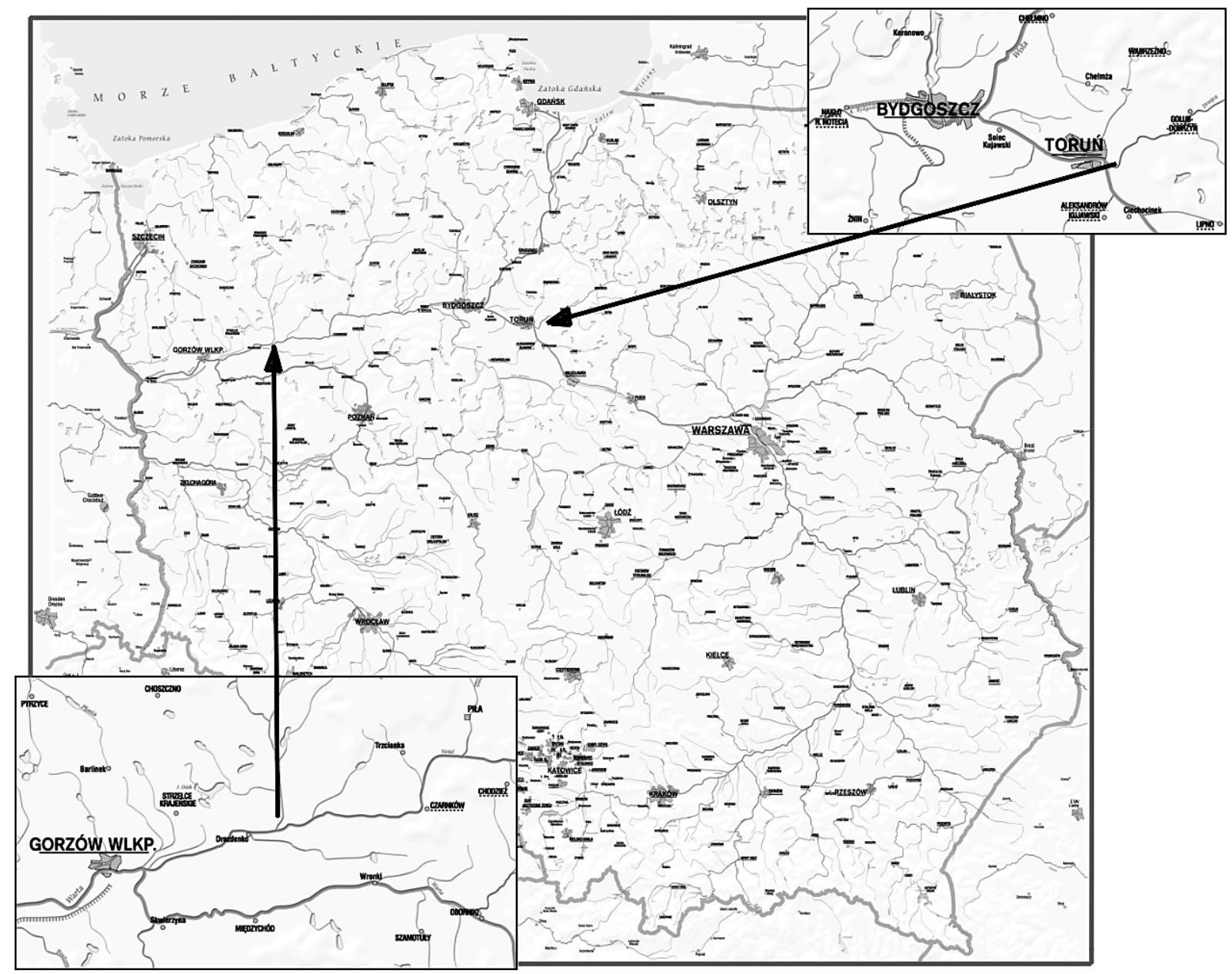

Fig. 15. Stocking areas of sturgeons into the Drwęca River (upper inset) and the Drawa River (lower inset)

\section{REFERENCES}

Anonymous 2009. Fishery Statistical Collections; Global Production. Fisheries and Aquaculture Department, Food and Agriculture Organization of The United Nations (FAO) http://www.fao.org/fishery/statistics/global-production/en.

Aoki T., Hirono I., Kurokawa K., Fukuda H., Nahary R., Eldar A., Davison A.J., Waltzek T.B., Bercovier H., Hedrick R.P. 2007. Genome sequences of three koi herpesvirus isolates representing the expanding distribution of an emerging disease threatening koi and common carp worldwide. Journal of Virology 81: 5058-5065. DOI: 10.1128/JVI.00146-07.

Bercovier H., Fishman Y., Nahary R., Sinai S., Zlotkin A., Eyngor M., Gilad O., Eldar A., Hedrick R. 2005. Cloning of the koi herpesvirus (KHV) gene encoding thymidine kinase and its use for a highly sensitive PCR based diagnosis. BMC Microbiology 5 (13): [without pagination.] DOI: 10.1186/1471-2180-5-13.

Bergmann S.M., Kempter J., Sadowski J., Fichtner D. 2006. First detection, confirmation and isolation of koi herpesvirus (KHV) in cultured common carp (Cyprinus carpio L.) in Bulletin of the European Association of Fish Pathologists 26: $97-104$.
Gilad O., Yun S., Andree K.B., Adkinson M.A., Zlotkin A., Bercovier H., Eldar A., Hedrick R.P. 2002. Initial characteristics of koi herpesvirus and development of a polymerase chain reaction assay to detect the virus in koi, Cyprinus carpio koi. Diseases of Aquatic Organisms 48: 101-108.

Gilad O., Yun S., Zagmutt-Vergara F.J., Leutenegger C.M., Bercovier H., Hedrick R.P., 2004. Concentrations of a Koi herpesvirus (KHV) in tissues of experimentally infected Cyprinus carpio koi as assessed by real-time TaqMan PCR. Diseases of Aquatic Organisms 60: 179-187.

Haenen O., Engelsma M.Y. 2004. Global distribution of KHV with particular reference to Europe. Pp. 13-15. In: International workshop on koi herpesvirus. London, 12-13 February 2004. Fisheries Resource Management Limited, Perthshire, Scotland. http://www.frmltd.com/Docs/FINAL\%20REPORT\%20-\%20KHV\%20WORKSHOP.pdf.

Haenen O., Hedrick R. 2006. Koi herpesvirus workshop. Bulletin of the European Association of Fish Pathologists 26: $26-37$.

Kempter J., Kielpiński M., Panicz R., Sadowski J. 2008a. Określenie nosicielstwa i podatności na infekcję koi-herpesvirusem wybranych gatunków ryb karpiowatych i ich krzyżówek pochodzących z wód otwartych i obiektów 
hodowlanych położonych w zlewni Odry [Determination of the carrier species and the infection susceptibility for KoiHerpes-Virus infections among selected cyprinid fish species and their hybrids acquired from open waters and culture sites of the Odra River drainage.] Wydawnictwo Akademii Rolniczej, Szczecin. [In Polish with English summary.]

Kempter J., Sadowski J., Kielpiński M., Panicz R., Bartłomiejczyk M. 2008b. Ocena zagrożenia wód naturalnych zlewni Odry wirusem „KHV” oraz wybranych gospodarstw karpiowych. (SPO RYBY projekt OR16-61535OR1600009/07). [Evaluation of the KHV threat to the Odra River drainage and selected fish farms.] Pp. 153-157. In: Szkolenie producentów ryb. Materiały szkoleniowe. [Workshop for Fish Farmers. Handouts.] 31 January-1 February 2008; Słok near Bełchatów, Poland. Polskie Towarzystwo Rybackie. [Polish Fisheries Society.] ISBN 83-60272-05-0. [In Polish.]

Kempter J., Sadowski J., Riecherdt M., Fichtner D., Bergmann S.M. 2007. First detection of koi herpesvirus (KHV) in Russian sturgeon (Acipenser gueldenstaedtii) and Atlantic sturgeon (Acipenser oxyrinchus). O15. Abstracts and program. 7th International symposium on viruses of lower vertebrates. Oslo, 22-25 April 2007. [Without pagination.]

Kolman R. (ed.) 2007. Restytucja jesiotra bałtyckiego. [Restitution of Baltic sturgeon.] Wydawnictwo Instytutu Rybactwa Śródlądowego, Olsztyn. [In Polish.]
Kolman R. 2008. Przeszłość, status gatunkowy i przyszłość jesiotra bałtyckiego Acipenser oxyrhynchus oxyrhynchus Mitchill. [The past, species status, and the future of the Baltic sturgeon (Acipenser oxyrhynchus oxyrhynchus Mitchill). P. 17. In: Actual [sic] status and active protection of sturgeon fish populations endangered by extinction. Aktualny stan i aktywna ochrona naturalnych populacji ryb jesiotrowatych zagrożonych wyginięciem. Scientific Conference; Program and abstracts; 5-7 March 2008; Przysiek near Toruń, Poland. Wydawnictwo Instytutu Rybactwa Śródlądowego, Olsztyn.

Kolman R., Szczepkowski M., Jankowska B., Kwiatkowska A., Sidorov N. 2005. The impact of Vitaton on the rearing parameters and meat quality of sturgeon hybrids. Archives of Polish Fisheries 13: 259-266.

Sadowski J., Kempter J. 2004. Nowa choroba wirusowa dużym zagrożeniem dla chowu karpia w Polsce. [A new viral disease - a serious threat to carp farming in Poland.] Komunikaty Rybackie 2004 (3): 35-38. [In Polish.]

Received: 17 April 2009

Accepted: 12 October 2009

Published electronically: 10 December 2009 